\title{
Legal Weak Protection of Personal Data in the 4.0 Industrial Revolution Era
}

\author{
Fenty U. Puluhulawa ${ }^{1}$ \\ Jufryanto Puluhulawa ${ }^{2}$ \\ M. Gufran Katili ${ }^{3}$ \\ 1Faculty of Law, Universitas Negeri Gorontalo, Indonesia. E-mail: fentypuluhulawa@ung.ac.id \\ 2 Faculty of Law, Universitas Negeri Gorontalo, Indonesia. E-mail: jufryantopuluhulawa@ung.ac.id \\ ${ }^{3}$ Faculty of Law, Universitas Negeri Gorontalo, Indonesia. E-mail: gufrankatili@gmail.com
}

\section{Info Artikel}

\section{Keywords:}

Legal protection;

Personal data;

Industrial revolution 4.0

\section{How to cite (APA \\ Citation Style): \\ Puluhulawa, F.U., Puluhulawa, J., Katili, G. (2020). "Legal Weak Protection of Personal Data in the 4.0 Industrial Revolution Era." Jambura Law Review, JALREV Vol 2 No (2): 182-200}

\begin{abstract}
Abstrak
This study aims to discuss the legal weak protection of personal data which is motivated by the phenomenon of society today which is like living in a world without borders so that it impacts on easy access to one's personal information, the impact of begins to spread illegal practices by irresponsible parties in the illegal use of personal information. In addition, there are no laws that specifically regulate the protection of personal data/information in the 4.0 Industrial Revolution era. The approach method used is a conceptual and case approach, with the purpose of the research is to analyze the weakness of legal protection for personal data in the 4.0 Industrial Revolution era in Indonesia. The results of the study, the spread of personal data protection arrangements in various laws and regulations indicate the protection of personal data is not yet a national legal priority and results in legal weak protection of the personal data of citizens so as to position Indonesian citizens in a vulnerable position, which is certainly not in line with the legal objectives namely provide legal certainty, justice, and expediency. The various cases that exist and pay attention to the phenomenon of digitalization in the era of the industrial revolution 4.0 illustrate the urgency of the need for the legal protection of personal data a state priority. Legal reform through the legitimacy of protecting personal data as a responsive and progressive legal policy is a must so that legal protection in the form of legal guarantees can be carried out properly in order to create a safe and comfortable digital ecosystem for the community.
\end{abstract}




\section{Introduction}

The problem of protecting personal data is serious today amid the rapid use of technology and information in the 4.0 Industrial Revolution era, creating conditions where personal data can easily become a broad public consumption. "This ongoing digital age has triggered an explosion in the growth of personal data created, stored, and transmitted on computers, internet sites, and even social media." 4 Sharing your full name, email address, cellphone number, and social media id account is something that happens in everyday life in this digitalization era. Various services in the form of applications embedded in electronic devices, often require the user's data, especially in the process of registering an account in the application as the main requirements for using the application, where the designation has various purposes depending on the policy of the application vendor. Based on the experience of researchers, most of these purposes are intended to verify the identity of the application used to obtain services from the application. One application vendor, Strongbee in his privacy policy, stressed that

"By visiting or using the Service and/or registering a STRONGBEE account, you agree and agree to the collection, use, disclosure, and processing of your Personal Data by this Privacy Policy. Please note that if you do not provide complete information as STRONGBEE requires, STRONGBEE may not be able to provide all of the services to you." 5

A similar policy was also made by the Linkaja Application, an application that provides electronic money services which the privacy policy states "We use user data to enable us to transmit the functions of the application / Site, resolve technical difficulties, provide you with the correct and up-to-date version of the application / Site, and to improve the function of the application / Site."6 These two applications are just examples, two of the many applications that are growing and present in the digital age,

\footnotetext{
${ }^{4}$ Shilling, C. G. (2011). "Privacy and Data Security: New Challenges of The Digital Age”. New Hampshire Bar Journal, 52 (2): 28.

5 Strongbee. (2020). "Privacy Policies”. Jakarta: PT Kreasi Lebah Aktif. Retrieved Februari 5, 2020, from https://strongbee.co.id/privacy_policies

6 LinkAja. (2020). “Kebijakan Privasi”. Retrieved Februari 5, 2020. https://www.linkaja.id/kebijakanprivasi.html.
} 
it seems that personal data is an important requirement for getting excellent service from the application.

Personal data is like a valuable asset, which in the view of M. Arsyad Sanusi "like a commodity with high economic value,"7 so it must be maintained and managed properly in today's digitalized world. Digitalization on the one hand brings benefits to civilization, but on the other hand, digitalization brings new problems as well as challenges in the 4.0 Industrial Revolution era. The rapid development of information and communication which includes "the stages of collecting, storing, processing, producing and sending data to and from industry or society effectively and efficiently" 8 not accompanied by optimal legal protection, as expressed by Wahyudi Djafar, "There is no adequate legal umbrella governing the matter of personal data protection in Indonesia. Regulations scattered in various laws have not yet fully referred to the principles of personal data protection." 9 The same thing was expressed by Ni Gusti Ayu Putu Nitayanti and Ni Made Ari Yuliartini Griadhi who stated that

“Until now, Indonesia doesn't have specific rules governing the protection of personal data. Arrangements regarding the protection of personal data are still separate in several laws and regulations, so a separate special regulation regarding the protection of personal data information is needed to create legal certainty." 10

In line with this statement, Donny B.U., The Expert Minister of Communication and Information in the field of Digital Literacy and Internet Governance stated that "at present, the substance of personal data protection is spread at least in 32 laws. Each of them overlaps because they are not integrated into the big concept of personal data

7 Sanusi, M. Arsyad. (2004). “Teknologi Informasi \& Hukum E-Commerce”. Jakarta: PT. Dian Ariesta. pg. 9

8 Dewi, Sinta. (2015). "Privasi atas Data Pribadi: Perlindungan Hukum dan Bentuk Pengaturan di Indonesia." Jurnal De Jure 15 (2): 165

9 Elnizar, Normand Edwin. (2019). "Perlindungan Data Pribadi Tersebar di 32 UU, Indonesia Perlu Regulasi Khusus". Retrieved Februari 2020. https://www.hukumonline.com/berita/baca/lt5d1c3962e01a4/perlindungan-data-pribadi-tersebardi-32-uu--indonesia-perlu-regulasi-khusus/

10 Ni Gusti Ayu Putu Nitayanti dan Ni Made Ari Yuliartini Griadhi. (2014). "Perlindungan Hukum Terhadap Informasi Pribadi Terkait Privacy Right Berdasarkan Undang-Undang Nomor 11 Tahun 2008 Tentang Informasi dan Transaksi Elektronik." Kertha Negara: Journal Ilmu Hukum (Universitas Udayana) 2 (5): 1-6. 
protection."11 So that within the scope of the use and utilization of personal data, placing it in conditions that are vulnerable to illegal actions by irresponsible partie.

A series of cases of personal data abuse colored the stage of digitalization in Indonesia in the era of the industrial revolution 4.0. Jakarta Legal aid colaborated with the Personal Data Protection Advocacy Coalition noted, "There are five thousand cases that depart from the misuse of personal data. Some cases, for example, personal data are used by individuals for sexual harassment, harassment, persecution, and data misuse for online lending."12 Medio mid-2019, "Twitter social media is horrified by the case of buying and selling data on identity cards and family cards worth millions of rupiah," and also the case of a senior Indonesian journalist, Ilham Bintang, "became a victim of the crime of theft of personal data with a SIM Swap Fraud which resulted in the burglary of the bank account concerned."13 This last case shows the weak protection of personal data law in the 4.0 Industrial Revolution era, because besides being a trending topic of social media and national media both print and online and attracting the attention of the public, what's interesting is that it involves one of the leading telecommunications vendors and banks in Indonesia, Indosat and the Commonwealth Bank. The latest case in 2020 is the leakage of users' data experienced by large startups that fall into the Unicorn and even Hectocorn categories. The leakage of users' personal data is certainly very dangerous because it puts the user in an unfavorable condition.

The writing of this law when compared with previous studies have similarities in terms of the topic of discussion, namely discussing personal data, but different from the main analysis which emphasizes the weakness of personal data protection in the 4.0 industrial revolution era and also the writing of this law moved from the many cases. Cases that are raised today, so writing this law becomes important because in addressing these cases legal research is needed as problem-solving.

\footnotetext{
11 Ibid.

12 Santoso, Bangun. (2019). "LBH Jakarta Terima 5000 Laporan Kasus Penyalahgunaan Data Pribadi”. Retrieved Februari 5, 2020. https://www.suara.com/news/2019/08/02/132914/lbh-jakarta-terima5000-laporan-kasus-penyalahgunaan-data-pribadi.

13 Nursalikah, Ani. (2020). "Pakar Digital Forensik Ungkap Modus Curi SIM Ilham Bintang”. Retrieved Februari 2020, 2020. https://republika.co.id/berita/q4d4d8366/pakar-digital-forensik-ungkapmodus-curi-sim-ilham-bintang.
} 


\section{Problem Statement}

Based on this background, the authors raise the problem namely about the cause of the legal weak protection of personal data in the era of Industrial Revolution 4.0 in Indonesia

\section{Method}

The approach method used in studying the problem is "the conceptual approach method in which this research focuses on the views and doctrines that develop in the science of law. By studying these views and doctrines, researchers will find ideas that give birth to legal understandings, legal concepts, and legal principles that are relevant to the issue at hand." 14 The author also uses a case approach by moving on some case data that the author obtained from various news sources which the author later described in the discussion to later become material for legal analysis.

\section{The cause of the legal weak protection of personal data in the era of Industrial} Revolution 4.0 in Indonesia

Southeast Asia Freedom of Expression Network (SAFEnet) notes, three things motivate the violation of personal data in Indonesia, namely

"firstly, an economic motive where there are illegal buying and selling of personal data of the Indonesian people which brings enormous potential profits, secondly, political motives by collecting personal data to be shown to the public to bring down political opponents and thirdly, threat motives in the hope of profiting from threatening actions using that personal data." 15

The main problem with the weak protection of personal data law is that until now there is no legal patron that explicitly covers the handling of legal issues of personal data misuse. The spread of personal data protection arrangements to various existing laws and regulations only seems like a gun without a bullet because the law enforcers must

\footnotetext{
14 Marzuki, Peter Mahmud. (2014). "Penelitian Hukum: Edisi Revisi”. Jakarta: Prenadamedia Group. Hlm.135-136

15 Annur, Cindy Mutia. (2019). "Pelanggaran Data Pribadi di Indonesia: Diperdagangkan Hingga Ancaman". Retrieved Februari 5, 2020. https://katadata.co.id/berita/2019/08/02/pelanggaran-datapribadi-di-indonesia-diperdagangkan-hingga-ancaman.
} 
mess around with the overlapping of existing rules and on the other hand, the current legal conditions in the view of researchers, indicate crimes against personal data, not a specific crime but a general crime. As a consequence, the handling is only general without special action needed, whereas, in the constitution of the Republic of Indonesia, Article 28G Paragraph (1) of the 1945 Constitution affirms "Every person has the right to protect themselves, family, honor, dignity, and property under his authority and entitled to a sense of security and protection from the threat of fear to do or not do something that is a human right."

In the international context, protection of personal data is regulated in Article 12 Universal Declaration of Human Rights, i.e. "No one shall be subjected to arbitrary interference with his privacy, family, home or correspondence, nor to attacks upon his honour and reputation. Everyone has the right to the protection of the law against such interference or attacks." Where according to Gudmundur, in this article 12 "the term privacy is considered as umbrella terms because it is associated with the protection of other rights, namely family, residence, the correspondence also includes respect and good name." 16 Other arrangements namely in Article 17 of the International Covenant on Civil and Political Rights which reads:

1. "No one shall be subjected to arbitrary or unlawful interference with his privacy, family, home or correspondence, nor to unlawful attacks on his honour and reputation"

2. "Everyone has the right to the protection of the law against such interference or attacks"

Reinforced in Article 32 of Law No. 39 of 1999 concerning Human Rights, which among others states that "independence and confidential communication via electronic means must not be disturbed except by order of a judge or other legal authority according to the law." It appears that the protection of personal data is a necessity to answer the mandate of existing legal instruments to guarantee the freedom, security, and dignity of citizens.

The current government, the reality only rests on the Minister of Communication and Information Regulation Number 20 of 2016 concerning Protection of Personal Data

\footnotetext{
16 Sinta Dewi. (2017). "Principles Of Personal Data Protection Customer Credit Card According To National Provisions And Implementations”. Sosiohumaniora, 19(3): 206-212
} 
established on November 7, 2016. This Ministerial Regulation is intended to fill the existing legal vacuum and this is a step forward in responding to the challenges of personal data protection in the era of the Industrial Revolution 4.0, however, it should be noted that in the hierarchy of statutory regulations as regulated in Law Number 12 of 2011 concerning Formation of Statutory Regulations, Ministerial Regulations are not in the hierarchy and only delegate to the formation of legislation. Delegation in the formation of laws and regulations is "removal/transfer of authority to form regulations from the original authority who delegates (delegans) to those who receive delegates (delegataris) with responsibility for exercising that authority to the delegataris themselves, whereas the responsibility of delegans is very limited." 17

The Ministerial Regulation is still under the law while many regulations regarding the protection of personal data are distributed in the form of legislation, moreover, Minister of Communication and Information Technology Regulation No. 20 of 2016 concerning Protection of Personal Data is a delegation of Government Regulation Number 82 of 2012 concerning Implementation Electronic Systems and Transactions are not statutory delegations. Also, other substantial deficiencies are the competence of institutions that adjudicate cases of misuse of personal data and forms of sanctions imposed on the misuse of personal data.

The distribution of personal data protection into various laws, based on the author's search, is contained in Act Number 23 of 2006 concerning Population Administration as amended by Act Number 24 of 2013 concerning Amendment to Law Number 23 of 2006 concerning Administration Population Article 1 number 22 of Law no. 24 of 2013 concerning Population Administration reads:

"Data Pribadi adalah data perseorangan tertentu yang disimpan, dirawat, dan dijaga kebenaran serta dilindungi kerahasiaannya."18

Then in Article 2 Chapter II of Law Number 23 of 2006 concerning Population Administration regulates that:

Setiap Penduduk mempunyai hak untuk memperoleh:

\footnotetext{
17 Attamimi, A. Hamid S. (1990). Disertasi "Peranan Keputusan Presiden Republik Indonesia Dalam Penyelenggaraan Pemerintahan Negara: Suatu Studi Analisis Mengenai Keputusan Presiden Yang Berfungsi Pengaturan Dalam Kurun Waktu Pelita I - Pelita VI." Pg. 347

18 Personal Data is certain personal data that is stored, maintained, and protected by the truth and confidentiality is protected (Coercive author)
} 
a. Dokumen Kependudukan;

b. pelayanan yang sama dalam Pendaftaran Penduduk dan Pencatatan Sipil;

c. perlindungan atas Data Pribadi;

d. kepastian hukum atas kepemilikan dokumen;

e. informasi mengenai data hasil Pendaftaran Penduduk dan Pencatatan Sipil atas dirinya dan/atau keluarganya; dan

f. ganti rugi dan pemulihan nama baik sebagai akibat kesalahan dalam Pendaftaran Penduduk dan Pencatatan Sipil serta penyalahgunaan Data Pribadi oleh Instansi Pelaksana. ${ }^{19}$

It is clear that residents' rights based on Law Number 23 of 2006 concerning Population Administration, one of which is the protection of personal data and violations against them are only subject to compensation and restoration of a good name. Surely this is not commensurate with the impact caused by personal data is something that is very sensitive if known by the public and then misused especially if it has to do with someone's disgrace. This is also emphasized in Article 32 of the Minister of Communication and Information Minister Regulation Number 20 of 2016 concerning Protection of Personal Data in the Electronic System which regulates the settlement of personal data disputes only through deliberation and civil lawsuits. Materially, it is indeed advantageous because it creates a win-win solution scheme but immaterial it certainly does not, moreover, dispute resolution through deliberation does not provide a deterrent effect in terms of prudent management of personal data by organizing an electronic system.

Utilization of personal data is also regulated in Government Regulation Number 40 of 2019 concerning the Implementation of Law Number 23 of 2006 concerning Population Administration as amended by Act Number 24 of 2013 concerning Amendment to Law Number 23 of 2006 concerning Population Administration in Article 58 paragraph (1) Government Regulation Number 40 of 2019 reads:

Kementerian/lembaga dan badan hukum Indonesia yang memperoleh Data

Pribadi Penduduk atau Data Kependudukan dilarang:

\footnotetext{
${ }^{19}$ Every resident has the right to obtain: a. Population Documents; b. the same service in Population Registration and Civil Registration; c. protection of Personal Data; d. legal certainty over document ownership; e. information regarding data on the results of Population Registration and Civil Registration of himself and/or his family; and f. compensation and restoration of a good name as a result of errors in Population Registration and Civil Registration as well as misuse of Personal Data by Implementing Agencies. (Coercive author)
} 


\section{1) "menggunakan Data Pribadi Penduduk atau Data Kependudukan} melampaui batas kewenangannya; atau

2) menjadikan Data Pribadi Penduduk atau Data Kependudukan sebagai bahan informasi publik sebelum mendapat persetujuan dari Menteri;

3) Pelanggaran atas ketentuan ini dikenakan sanksi administratif berupa pencabutan hak akses pengguna, pemusnahan data yang sudah diakses, dan denda administratif sebesar Rp10 miliar."20

If Law Number 23 of 2006 concerning Population Administration confirms the protection of personal data as a resident's right and violations there are subject to civil sanctions in the form of compensation and rehabilitation of the good name, then Government Regulation Number 40 of 2019 only imposes administrative sanctions in the process if it sees Article 29 of the Regulation Minister of Communication and Information Number 20 of 2016 Regarding Protection of Personal Data in the Electronic System was preceded by a complaint to the minister. This is interesting because the extent to which the minister's decision has a binding legal force to resolve personal data disputes while providing legal protection for the parties to the dispute.

Speaking of personal data, it is also not spared to see the regulation of Law Number 11 of 2008 concerning Information and Electronic Transactions, finally amended by Act Number 19 of 2016 concerning Amendment to Law Number 11 of 2008 concerning Information and Electronic Transactions in Article 30 regulates hacking / hacking committed by individuals whose sanctions are in the form of criminal sanctions provided for in Article 46 but this regulation is only for individuals who commit hacking while their electronic system managers are not subject to criminal sanctions for the weakness of their security systems which results in the failure of data protection. personal. Even in Act Number 11 of 2008 concerning Information and Electronic Transactions was finally amended by Act Number 19 of 2016 concerning Amendment to Act Number 11 of 2008 concerning Electronic Information and Transactions, it was not specifically regulated regarding the settlement of personal

\footnotetext{
20 Indonesian ministries/institutions and legal entities that obtain Population Personal Data or Population Data are prohibited from 1) "using Population Personal Data or Population Data exceeds the limits of its authority; or 2) make Population Personal Data or Population Data as public information material before obtaining approval from the Minister; 3) Violations of this provision are subject to administrative sanctions in the form of revocation of user access rights, destruction of data that has been accessed, and administrative fines of Rp10 billion." (Coercive author)
} 
data disputes when in fact this law can be said to be the main spearhead in the digital jurisdiction.

Based on the data recapitulation of the Ministry of Communication and Information of the Republic of Indonesia, "as of March 2020, overall there were 44 cases of violations of information security, while the derivative cases that were still related to information security violations, in this case, personal data, namely fraud amounted to 9,458 cases." 21 The numbers are still small but considering our culture of the digital economy which has just grown and the financial losses incurred, this must be anticipated immediately so that the law does not always lag with the development of the society it governs so that it can be in line with the progressive legal concept put forward by Satjipto Rahardjo who believes that "hukum hendaknya mampu menjawab perubahan zaman dengan segala dasar didalamnya. (The law should be able to answer the changing times with all the basics in it.)"22

The latest case amidst the hustle and bustle of the COVID-19 pandemic involving leading startups in Indonesia is the leaking of Tokopedia platform user data, as reported by Kompas.com

"Data belonging to 15 million users of Tokopedia allegedly leaked in cyberspace. The latest news mentions data 91 million users and more than seven million merchants Tokopedia sold on dark sites (dark web). The data is sold at 5,000 US dollars (around Rp. 74 million). This incident will certainly harm the affected users. The victim's e-mail has the potential to be misused for crime, for example, fraud or extortion. Tokopedia recognizes the existence of attempts to steal user data on its e-commerce platform." 23

It can be seen that the impact caused by the leaking of personal data is massive. Only one case but the potential to cause millions of losses and even billions of dollars. No less with Tokopedia, its closest competitor Bukalapak also suffered the same fate, CNN Indonesia reported "Data of 13 million leaked Bukalapak accounts are being traded on the RaidForums hacker forum. The data traded displays emails, usernames, passwords,

${ }^{21}$ Kementerian Komunikasi dan Informasi. (2020). "Statistik Aduan". Retrieved Mei 14, 2020, from Kementerian Komunikasi dan Informasi: https://www.kominfo.go.id/statistik

22 Satjipto Rahardjo. (2006). "Menggagas Hukum Progresif Indonesia". Yogyakarta: Pustaka Pelajar. Pg. 1

${ }^{23}$ Wahyunanda Kusuma Pertiwi. (2020). "Data Pengguna Tokopedia Bocor, Cek Apakah Akun Anda Terdampak". Retrieved Mei 15, 2020, from Kompas.com: https://tekno.kompas.com/read/2020/05/03/11580057/data-pengguna-tokopedia-bocor-cekapakah-akun-anda-terdampak 
salt, last logins, Facebook emails with hashes, user addresses, birthdays, and phone numbers." 24

Facebook as one of the most popular social media in Indonesia and even the world has experienced a leak of user data since the last few years, even the most recent in December 2019 "after several cases of data leakage tripping, this time before closing in 2019, there are 267 million user data related Facebook ID, contact number, and the full name of Facebook users who have spread on the Internet through a forum."25

Internationally, based on the data from the World's Biggest Data Breaches and hacks, as of 1 April 2019 published in LokaData, several other large companies also did not escape the data leakage illustrated in the following figure:

\section{0 perusaahan dengan kebocoran data terbanyak, 2019}

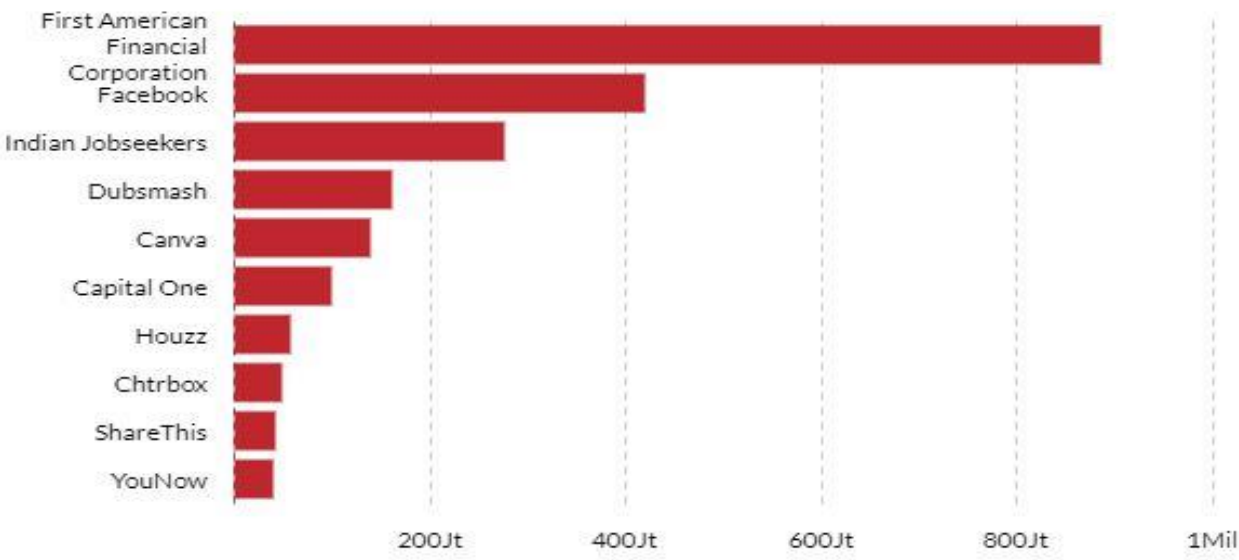

Picture 1. Data on the top 10 digital companies that experienced the most data leakages in 201926

It is noteworthy, of the 10 companies with the most data leaks in the middle of 2019, Facebook, Dubsmash and Canva are the digital platforms with quite a lot of users in

\footnotetext{
${ }^{24}$ CNN Indonesia. (2020). “13 Juta Data Bocor Bukalapak Dijual di Forum Hacker”. Retrieved Mei 15, 2020, from CNN Indonesia: https://www.cnnindonesia.com/teknologi/20200506065657-185500477/13-juta-data-bocor-bukalapak-dijual-di-forum-hacker

25 Cahyandaru Kuncorojati. (2019). “Facebook Bocor Lagi, 267 Juta Data Pengguna Tersebar”. Retrieved Mei 15, 2020, from Medcom.id: https://www.medcom.id/teknologi/news-teknologi/RkjzOr9kfacebook-bocor-lagi-267-juta-data-pengguna-tersebar

26 LokaData. (2019). “10 Perusahaan Dengan Kebocoran Data Terbanyak, 2019”. From LokaData: https://lokadata.id/data/10-perusaahan-dengan-kebocoran-data-terbanyak-2019-1568352493. Retrieved 15 Mei 2020.
} 
Indonesia, so this requires appropriate anticipatory steps from the Government of Indonesia to provide legal protection and guarantees to its citizens.

The online meeting application which is again rising in popularity at this time namely Zoom is also not spared from the leakage of users' data. CNBC Indonesia reported that “530.000 password data and Zoom user application account details have been traded hackers on the Dark Web."27 This data leakage experienced by Zoom was immediately taken seriously by the Ministry of Defense of the Republic of Indonesia by issuing "an internal circular numbered SE / 57 / IV / 2020 signed by the Secretary-General of the Ministry of Defense, Vice Admiral Agus Setiadji on April 21, 2020." The substance of this circular regulates the prohibition of using the zoom application within the Ministry of Defense of the Republic of Indonesia. The internal prohibition on using the Zoom application is based on the consideration that there is no guarantee of user data protection from the manager of the zoom application.

Interestingly, when the COVID-19 pandemic that hit Indonesia today, which took place since early 2020, personal data from patients with COVID-19 also spread widely so easily through chain messages in various online media such as Whatsapp and Facebook. This scattered personal data covers the full name, age, residential address, and even displays a profile photo of the person concerned. In addition to causing the personal data of the patient concerned to be vulnerable to abuse by irresponsible parties, on the other hand, psychologically makes the patient stressed and mentally disturbed.

This results in a psychological effect, where it is expected that someone can recover physically even sicker because of his mind and mental illness as well as the effects of stress which cause emotional reactions which include "anxiety, anger, and aggression, as well as apathy and depression,"28 as testimony from Patient 03 COVID-19 in Indonesia, who has now recovered, said 29

27 CNBC Indonesia. (2020). “Kacau, 530.000 Data Akun Zoom Dijual Hacker di Dark Web”. Retrieved from CNBC Indonesia: https://www.cnbcindonesia.com/tech/20200416082700-37-152270/kacau530000-data-akun-zoom-dijual-hacker-di-dark-web. Retrieved 31 Mei 2020

28 Eunike, R. Rustiana dan Widya Hary Cahyati. (2012). "Work Stress With Selection Of Coping Strategies". Jurnal Kesehatan Masyarakat, 7(2): 149-155.

${ }^{29}$ Fitri Syarifah. (2020). "Cerita Pasien COVID-19 yang Sembuh, Menangis Seminggu karena Data Pribadi Bocor". Retrieved Mei 15, 2020, from 
"Due to the inaccurate dissemination of information by parties who are not responsible for disturbing our minds and mental health during treatment. Our identity is not protected. This caused panic in the community and I was treated for a week crying constantly because of stress."

Other related news is also published by Suara.com,"30 "confidentiality of patient data/suspect COVID-19 is not guaranteed confidentiality and this condition is exacerbated by the release of the Hospital's hands and the absence of follow-up from the Police to investigate the leaking of personal data." Of course, this phenomenon is very sad, people seem to forget or may not realize that spreading personal identity has a very detrimental impact on their victims.

Digital expert and Director of Kernels Indonesia (Drone Emprit), Ismail Fahmi, told CNN Indonesia that the risk of cybercrime that could result from the leaking of personal data of users is: ${ }^{31}$

\section{1. "Telemarketing}

Telephone number data can be traded so don't be surprised if we get a telephone or SMS with a product/service offering with prizes;

2. Phishing Scamming Fraud Model

Fraud by ensuring that users win certain prizes obtained if they give some money or direct users to provide personal data while pointing to fake sites;

3. Breakdown of other services

Leaked data can be used to access accounts on other integrated social/online services such as Go Pay, Instagram, etc.;

4. Dismantling the password/password

Date of birth and e-mail that is leaked can also be a hacker's capital to take over the account;

5. Used to create an online loan account secretly

Criminals can also apply for loans in online loan applications with the data that has been leaked;

6. Profiling for political targets or social media advertising

https://www.liputan6.com/health/read/4203463/cerita-pasien-COVID-19-yang-sembuh-menangisseminggu-karena-data-pribadi-bocor\#

30 Dythia Novianty dan Lintang S. Utami. (2020). "Namanya Tersebar, Warganet Sebut Ada Kebocoran Data Pasien Virus Corona". Retrieved Mei 15, 2020, from Suara.com: https://www.suara.com/tekno/2020/03/26/063000/namanya-tersebar-warganet-sebut-adakebocoran-data-pasien-virus-corona

31 CNN Indonesia. (2020). “6 Bahaya yang Intai Usai Kasus Data Bocor Tokopedia-Bukalapak." Retrieved Mei 15, 2020, from CNN Indonesia: https://www.cnnindonesia.com/teknologi/20200506105640-185500591/6-bahaya-yang-intai-usai-kasus-data-bocor-tokopedia-bukalapak 
Personal data taken can be used for social engineering to profiling which results in the driving of public opinion."

Potential threats of a crime arising from the leaking of personal data according to Rathore et.al as quoted by Vannyora Okditazeini and Irwansyah, including covering "threats to multimedia content in the form of content manipulation and steganography, then traditional threats in the form of phishing, malware, sybil attacks, and fake profiles, spamming, deanonymization attacks, profile cloning attacks and social threats including cyber-bullying and cyber-stalking."32

The author is of the view, moving on from the various cases presented along with the elaboration of their impact, it needs quick steps for the government to immediately make legal reforms to improve the weak protection of personal data law by making special laws related to the protection of personal data as a responsive legal policy whereby "The law as a means of response to social provisions and the aspirations of the community" 33 and progressive wherein "the law must serve the interests of citizens"34 so that legal protection in the form of legal guarantees can be carried out properly to create a safe and comfortable digital ecosystem for the community that has an impact on economic growth and public welfare as the legal goals set forth by Nonet and Sleznick that "the law must truly prosper the community in the interests of bigger, not only for the interests of those in power."35

It is worth noting that the legal instrument for protecting personal data will later fulfill several criteria, according to Sinta Dewi Rosadi and Garry Gumelar Pratama, that "have an international character, protect the privacy and personal data as positive rights and are an element of individual glue and economic society."36

\footnotetext{
32 Vannyora Okditazeini dan Irwansyah. (2018). "Threat on Privacy And Data Mining In Digital Era: A Meta-Synthesis Analysis On Social Networking Sites (Sns)". Jurnal Studi Komunikasi dan Media, 22(2): 109-122

33 Retno Saraswati. (2013). "Problematika Hukum Undang-Undang No. 12 Tahun 2011 Tentang Pembentukan Peraturan Perundang-Undangan". Jurnal Yustisia, 2 (3): 97-103

34 Marilang. (2017). “Considering the Progressive Legal Justice Paradigm”. Jurnal Konstitusi, 14 (2): 315 331

35 Marwan Effendy. (2014). "Teori Hukum dari Perspektif Kebijakan, Perbandingan dan Harmonisasi Hukum Pidana”. Jakarta: Referensi Gaung Persada Group. Pg. 25

36 Sinta Dewi Rosadi dan Garry Gumelar Pratama. (2018). "Perlindungan Privasi dan Data Pribadi Dalam Era Ekonomi Digital di Indonesia”. Veritas et Justicia, 4 (1): 88-110
} 
The Government of Indonesia itself can learn from the legal policies adopted in several developed countries in terms of formulating personal data legal protection, such as "Britain with the Data Protection Act 1998 which came into force in 2000, Malaysia through the Personal Data Protection Act (PDPA) 2010 which was imposed on August 2013, Singapore with the 2012 Personal Data Protection Act (PDPA) effective from July 2014."37 "Personal Data Protection in Argentina, Law on Protection of Personal and Electronic Document Information in Canada, Personal Data Protection Law in Japan, Information Technology Regulation in India, Personal Information Protection Law in South Korea and the United States with US Privacy Law and California Consumer Privacy Law." 38 "Portugal has even included the protection of personal data as a constitutional right in its constitution."39

There are also several international instruments governing the protection of personal data such as:

a. "The Council of Europe Convention for the Protection of Individual swith regard to Automatic Processing of Personal Data (No. 108), 1981;

b. The Organization for Economic Cooperation and Development Guidelines on the Protection of Privacy and Transborder Data Flows of Personal Data (1980); and

c. The Guidelines for the regulation of computerized personal data files (General Assembly resolution 45/95 and E/CN.4/1990/72)." 40

It is time for Indonesia to improve and immediately adapt to current global developments. The problem of legal protection regulations for personal data that is scattered in various regulations in Indonesia must be resolved immediately. Too many personal data protection rules make the regulations that govern them fat, ineffective, and inefficient. This is like a sandcastle, which looks magnificent but fragile. The consequence that arises is the clash in the field in the process of law enforcement and legal protection as a correlation of overlapping rules which of course will complicate

37 Rosalinda Elsina Latumahina. (2014). Aspek Hukum Perlindungan Data Pribadi di Dunia Maya. Gema Aktualita, 3(2), 14-25

38 Fanny Priscyllia. (2019). "Perlindungan Privasi Data Pribadi Perspektif Perbandingan Hukum". Jatiswara, 34 (3): 239-249

39 Sinta Dewi. (2016). “Konsep Perlindungan Hukum Atas Privasi Dan Data Pribadi Dikaitkan Dengan Penggunaan Cloud Computing di Indonesia". Yustisia, 5 (1): 22-30

40 Ibid 
the government and law enforcement agencies and become a barrier that complicates development and economic acceleration.

\section{Conclusion}

The spread of legal arrangements regarding personal data in Indonesia to various rules that do not specifically regulate the protection of personal data is a serious problem that weakens the legal protection of personal data in Indonesia so it must be resolved immediately through legal reform. Dissemination of regulations in various laws and regulations in addition to indicating the protection of personal data is not yet a national legal priority, it also results in legal weak protection of personal data of citizens to position Indonesian citizens in vulnerable positions, which is certainly not in line with the legal objectives of providing legal certainty, justice and expediency. Various cases that exist and pay attention to the phenomenon of digitalization in the era of the industrial revolution 4.0 and the development of the world today should be legal protection of personal data a priority of the country.

\section{References}

\section{Book by Author:}

Effendy, Marwan. (2014). Teori Hukum Dari Perspektif Kebijakan, Perbandingan dan Harmonisasi Hukum Pidana. Jakarta: Referensi Gaung Persada Group.

Marzuki, Peter Mahmud. (2014). Penelitian Hukum : Edisi Revisi. Jakarta: Prenadamedia Group.

Rahardjo, Satjipto. (2006). Menggagas Hukum Progresif Indonesia. Yogyakarta: Pustaka Pelajar.

Sanusi, M. Arsyad. (2004). Teknologi Informasi \& Hukum E-Commerce. Jakarta: PT. Dian Ariesta.

\section{Journal Article:}

Dewi, Sinta. (2015). Privasi atas Data Pribadi: Perlindungan Hukum dan Bentuk Pengaturan di Indonesia. Jurnal De Jure, 15(2), 165.

------ (2016). Konsep Perlindungan Hukum Atas Privasi Dan Data Pribadi Dikaitkan Dengan Penggunaan Cloud Computing Di Indonesia. Yustisia, 5(1), 22-30.

------ (2017). Principles Of Personal Data Protection Customer Credit Card According To National Provisions And Implementations. Sosiohumaniora, 19(3), 206-212. 
Eunike, R. Rustiana dan Widya H. Cahyati. (2012). Work Stress With Selection Of Coping Strategies. Jurnal Kesehatan Masyarakat, 7(2), 149-155.

Latumahina, Rosalinda Elsina. (2014). Aspek Hukum Perlindungan Data Pribadi di Dunia Maya. Gema Aktualita, 3(2), 14-25.

Marilang. (2017). Considering The Progressive Legal Justice Paradigm. Jurnal Konstitusi, 14(2), 315-331.

Nitayanti, Ni Gusti Ayu Putu dan Ni Made Ari Yuliartini Griadhi. (2014). Perlindungan Hukum Terhadap Informasi Pribadi Terkait Privacy Right Berdasarkan UndangUndang Nomor 11 Tahun 2008 Tentang Informasi dan Transaksi Elektronik. Kertha Negara : Journal Ilmu Hukum, 2(5), 1-6.

Okditazeini, V. \& Irwansyah. (2018). Threat On Privacy And Data Mining In Digital Era: A Meta-Synthesis Analysis On Social Networking Sites (Sns). Jurnal Studi Komunikasi dan Media, 22(2), 109-122.

Rosadi, S. D. dan Garry Gumelar Pratama. (2018). Perlindungann Privasi dan Data Pribadi Dalam Era Ekonomi Digital di Indonesia. Veritas et Justicia, 4(1), 88-110.

Priscyllia, F. (2019). Perlindungan Privasi Data Pribadi Perspektif Perbandingan Hukum. Jatiswara, 34(3), 239-249.

Saraswati, R. (2013). Problematika Hukum Undang-Undang No. 12 Tahun 2011 Tentang Pembentukan Peraturan Perundang-Undangan. Yustisia, 2(3), 97-103.

Shilling, C. G. (2011). Privacy and Data Security: New Challenges of The Digital Age. New Hampshire Bar Journal, 28.

\section{Report:}

Attamimi, A. Hamid. (1990). Peranan Keputusan Presiden Republik Indonesia Dalam Penyelenggaraan Pemerintahan Negara: Suatu Studi Analisis Mengenai Keputusan Presiden Yang Berfungsi Pengaturan Dalam Kurun Waktu Pelita I Pelita VI. Disertasi. Jakarta: Pasca Sarja Universitas Indonesia.

\section{Official Web:}

Annur, Cindy Mutia. (2019). Pelanggaran Data Pribadi di Indonesia : Diperdagangkan Hingga Ancaman. Retrieved Februari 5, 2020, from https://katadata.co.id/berita/2019/08/02/pelanggaran-data-pribadi-diindonesia-diperdagangkan-hingga-ancaman

Batubara, Herianto. (2019). Viral Data e-KTP dan KK diperjualbelikan, ini respons Mendagri. Retrieved Februari 5, 2020, from https://news.detik.com/berita/d4641739/viral-data-e-ktp-dan-kk-warga-diperjualbelikan-ini-responskemendagri 
Elnizar, Normand Edwin. (2019). Perlindungan Data Pribadi Tersebar di 32 UU, Indonesia Perlu Regulasi Khusus. Retrieved Februari 5, 2020, from https://www.hukumonline.com/berita/baca/lt5d1c3962e01a4/perlindungan -data-pribadi-tersebar-di-32-uu--indonesia-perlu-regulasi-khusus/

Indonesia, CNN. (2020, Mei 6). 13 Juta Data Bocor Bukalapak Dijual di Forum Hacker. Retrieved Mei 15, 2020, from CNN Indonesia: https://www.cnnindonesia.com/teknologi/20200506065657-185-

500477/13-juta-data-bocor-bukalapak-dijual-di-forum-hacker

------. (2020, Mei 6). 6 Bahaya yang Intai Usai Kasus Data Bocor Tokopedia-Bukalapak. Retrieved Mei 15, 2020, from CNN Indonesia: https://www.cnnindonesia.com/teknologi/20200506105640-185-500591/6bahaya-yang-intai-usai-kasus-data-bocor-tokopedia-bukalapak

------. (2020). Kacau, 530.000 Data Akun Zoom Dijual Hacker di Dark Web. Retrieved from CNBC Indonesia: https://www.cnbcindonesia.com/tech/20200416082700-37-152270/kacau530000-data-akun-zoom-dijual-hacker-di-dark-web

Informasi, Kementerian Komunikasi. (2020). Statistik Aduan. Retrieved Mei 14, 2020, from Kementerian Komunikasi dan Informasi: https://www.kominfo.go.id/statistik

JPNN.Com. (2020). Kementerian Pertahanan Terbitkan Edaran Penting Soal Zoom. Retrieved from JPNN.Com: https://www.jpnn.com/news/kementerianpertahanan-terbitkan-edaran-penting-soal-zoom

Kuncorojati, Cahyandaru. (2019). Facebook Bocor Lagi, 267 Juta Data Pengguna Tersebar. Retrieved Mei 15, 2020, from Medcom.id: https://www.medcom.id/teknologi/news-teknologi/Rkjz0r9k-facebookbocor-lagi-267-juta-data-pengguna-tersebar

LinkAja. (2020). Kebijakan Privasi. Retrieved Februari 5, 2020, from https://www.linkaja.id/kebijakan-privasi.html

LokaData. (2019). 10 Perusahaan Dengan Kebocoran Data Terbanyak, 2019. Retrieved Mei 15, 2020, from LokaData: https://lokadata.id/data/10-perusaahandengan-kebocoran-data-terbanyak-2019-1568352493

Novianty, Dythia. (2020). Namanya Tersebar, Warganet Sebut Ada Kebocoran Data Pasien Virus Corona. Retrieved Mei 15, 2020, from Suara.com: https://www.suara.com/tekno/2020/03/26/063000/namanya-tersebarwarganet-sebut-ada-kebocoran-data-pasien-virus-corona

Nursalikah, Ani. (2020). Pakar Digital Forensik Ungkap Modus Curi SIM Ilham Bintang. Retrieved

Februari

2020 ,

2020

from 
https://republika.co.id/berita/q4d4d8366/pakar-digital-forensik-ungkapmodus-curi-sim-ilham-bintang

Pertiwi, Wahyunanda Kusuma. (2020, Mei 3). Data Pengguna Tokopedia Bocor, Cek Apakah Akun Anda Terdampak. Retrieved Mei 15, 2020, from Kompas.com: https://tekno.kompas.com/read/2020/05/03/11580057/data-penggunatokopedia-bocor-cek-apakah-akun-anda-terdampak

Santoso, Bangun. (2019). LBH Jakarta Terima 5000 Laporan Kasus Penyalahgunaan Data Pribadi. Retrieved Februari 5, 2020, from https://www.suara.com/news/2019/08/02/132914/lbh-jakarta-terima5000-laporan-kasus-penyalahgunaan-data-pribadi

Strongbee. (2020). Privacy Policies. Jakarta: PT Kreasi Lebah Aktif. Retrieved Februari 5,2020 , from https://strongbee.co.id/privacy_policies

Syarifah, Fitri. (2020). Cerita Pasien COVID-19 yang Sembuh, Menangis Seminggu karena Data Pribadi Bocor. Retrieved Mei 15, 2020, from Liputan6.com: https://www.liputan6.com/health/read/4203463/cerita-pasien-covid-19yang-sembuh-menangis-seminggu-karena-data-pribadi-bocor\# 